\title{
"SO WERE I EQUALLED IN RENOWN": AUTOBIOGRAPHICAL ELEMENTS AND THE EPIC POET'S CAREER IN MILTON
}

\author{
Andrey Felipe Martins ${ }^{{ }^{*}}$ \\ Maria Rita Drumond Viana ${ }^{2 * *}$ \\ ${ }^{1,2}$ Universidade Federal de Santa Catarina, Florianópolis, Santa Catarina, Brasil
}

\begin{abstract}
John Milton is outlier among poets of the seventeenth century in his extensive recourse to details of his personal life, which are made integral part, covertly or explicitly, of his many works. From the early "Nativity Ode" onwards we can identify confessional passages in many of his poems that can be read autobiographically. What draws our attention to Milton's case is that it also prefigures a major cultural and political revolution, in which the legitimacy of the individual consciousness was revalued. The main aim of this article is to explore specific moments in Milton's oeuvre in which the autobiographical vein comes into sharp focus. Differently from his more mature work, in which he does not waver in confidence, in the earlier writings we can identify the doubts and anxieties of an apprentice poet of unbounded aspiration.

Keywords: John Milton; On the Morning of Christ's Nativity; Lycidas; Paradise Lost; Autobiography; Seventeenth-century Poetry.
\end{abstract}

\footnotetext{
"MA student in the Graduate Program in English Language/Literature (PPGI) at the Universidade Federal de Santa Catarina (UFSC). He is currently writing a thesis which consists on a queer reading of Wuthering Heights, under the supervision of Eliana de Souza Ávila. His research interests, however, also include early modern poetry. His email address is: andreymartins3@hotmail.com. ORCID: 0000-0003-2193-3216.

${ }^{* *}$ Lecturer and researcher in the Department of Foreign Languages and Literatures at UFSC. She also teaches and supervises postgraduate students at the Programmes in English (PPGI) and Translation Studies (PGET). Her main research focuses on the theoretical aspects of life writing and on writers' correspondences. Her email address is: m.rita.viana@ufsc.br. ORCID: 0000-0002-1985-3375.
} 
John Milton is outlier among poets of the seventeenth century in his extensive recourse to details of his personal life, which are made integral part, covertly or explicitly, of his many works. From the early "Nativity Ode" (1629), in which he celebrates the metaphorical birth of his poetic voice, to the anxieties concerning virginity in Comus (1634) and his disillusionment in the late Samson Agonistes (1671), we can identify confessional passages in many of his poems that can be read autobiographically. Moreover, although such foregrounded intertwinement of work and life might be expected of artists from the Romantic tradition and its inheritants, what draws our attention to Milton's case is that it also prefigures a major cultural and political revolution, in which the legitimacy of the individual consciousness was revalued.

The first question that is posed to any study which deals with the influence of a writer's life in his literary production is the extent to which the latter can be approached autobiographically. This is by no means a simple question, as the definition of autobiography is not a matter of consensus; this field of studies, reinvigorated theoretically since the 1960s, is heterogeneous in form. As James Olney remarks, there can scarcely be two authors who completely agree with each other in their definition of "autobiography". Olney, for one, can be ranked among those whose theory tends to be more comprehensive, so that, for example, in the beginning of his Metaphors of the Self he defends the idea that it is not profitable to approach autobiography formally or historically. In contrast, on the opposite end of the spectrum, there are authors like Philippe Lejeune who have engaged in developing complex taxonomies and practically a checklist of conditions. As the next section makes clear, we here are interested in autobiography at a specific historical point, as a reflex of the changes that the understanding of the "self" was going through in mid-seventeenth century, and in relation to other genres that prefigure it.

Even though Olney's more thematic approach is not completely endorsed here, there is a sense in which his formulations are of special relevance for Milton. His diachronic and author-centred view that "a man's lifework is his fullest autobiography" leads to the conclusion that "there is a creative vitality that informs all the volumes of his collected works" (2). He remarks that Heraclitus, for example, was the first to "project a cosmology that consciously reflected himself... at its centre" (9). This unexpected notion of a cosmology which is rooted in human consciousness can be glimpsed in Paradise Lost, as one of the poem's rhetoric strategies is that the poet seeks the muse, a convention of epic poetry, not only for poetic inspiration, but as a means to embrace the cosmos in its wake. The architecture of the universe is informed by his creative force analogously to the way in which an author is said by Olney to pervade his writings. This is all the more meaningful once we take into account that a type of vitalism in which all matter "was infused with a rational spirit or a motivated force" (Rogers 12) by the creator was essential to Milton's metaphysics in the 1650s.

Therefore, the main aim of this article is to explore specific moments in Milton's oeuvre in which the autobiographical vein comes into sharp focus. 
Differently from his more mature work, in which he does not waver in confidence, in the earlier writings we can identify the doubts and anxieties of an apprentice poet of unbounded aspiration. The theme that invariably arises is that of the career of the poet, hence the progress of this motif in his writings is our sewing thread. We start discussing the confessional character of the tension between "paganism" (via the classics) and Christianity in the "Nativity Ode," the poem that marks Milton's birth, as the confession has often been seen as a forerunner of autobiography. We analyse specifically how Milton establishes a dialogue with and re-signifies the Augustinian tradition of confession. In the sequence, the discussion turns to his more "youthful" concerns, as the poet confronts his fear of poetical failure in the pastoral "Lycidas." Finally, the article concludes with an analysis of the invocation to light in book III of Paradise Lost, given that the subject of the loss of the eyesight therein dealt with in it is especially important from the perspective of autobiography.

\section{The Trust in the Inner Light: The "Self" in Transition}

Modern discussions of autobiography can be traced back to late eighteenth century. As James Treadwell remarks, there had certainly been a proliferation of other types of self-writing prior to the 1790s, but a term which could comprehend these heterogeneous texts, giving shape to a new field of studies, was online coined in 1797 by Norwich essayist William Taylor, who proposes it ("autobiography") as an alternative to what he considered a blunt neologism, "self-biography" (3). As is often the case, events, facts and practices that have existed in society for a considerable amount of time usually only get a name in retrospect in the hands of future generations. Therefore, even though autobiography became a self-aware genre in the vicinity of the French Revolution, the seeds of what we regard as a distinguishing tenet of modernity - the individual's inalienable freedom and existence as entity -can be seen to be already at work at another important revolution, which predates the French by a century. The idea that "man" (in their own terms) is essentially free had already acted as a determining element in the English Revolution of the seventeenth century. ${ }^{1}$ Thus, as we are dealing with a poet from that specific period, we intend to explore notions of early modern subjectivity and its figurations here. We argue that the element of secularization distinguishes the notion of interiority in Milton's context from that of the period of modern autobiography's rise to eminence. Milton still operates within a fairly theological mind-set (in the same way that, say, Locke uses theological arguments for secular ends) and therefore necessary reservation must be made in order to maintain the differences implied by this mediation of religion. ${ }^{2}$ Moreover, we must also take into account oscillations in the poet's own estimation of the potentialities and the limits of individual freedom throughout his life.

As Matthew Jordan points out, although the OED lists the first appearance of the word "self-esteem" in 1657, Milton had already used it in 1642 in An Apology against a Pamphlet, so that perhaps he was the first to coin it. The 
matter of priority aside, the fact that not only this but many new compounds with the prefix "self" were created in the 1640s and 50s is a linguistic record of "a profound cultural shift" (4). The early and mid-seventeenth century was marked by a religious as well as an economic change in England, which provoked a revolution in the way people start to understand themselves. While a sharp distinction between medieval "dark" ages and modernity is too simplistic, still it is undeniable that the emphasis of these neologisms on the individual points to an embryonic stage of "interiorized self-recognition," in Jordan's words, which is characteristic of bourgeois subjectivity. In the religious realm, it must not be forgotten, this recognition had at first a clearly subversive aspect. If the Sermon of the Mountain urges Christians not only to obey but internalise the law, we can see in the Puritan reliance on a stable internal moral of the individual believer a consummation of the ideas already contained in the Gospels. God prefers "the upright heart and pure," declares Milton in a Biblical allusion in the opening of Paradise Lost. If, on the one hand, it leads to the proverbial self-righteousness of Puritans, on the other the revolution caused by these ideals was the occasion for a serious blow at the currently corrupt structure of the Catholic and Established Churches in Great Britain. It brought about a decentralisation of the hermeneutic practices, redistributing it from exclusively the hands of the clergy and making anyone a potential interpreter and even prophet. Nevertheless, the limits of this atomistic individuality, to Milton's great distress, might be sensed in the fact that once the "presbyters" assumed power they started to behave as their forerunners, as shown in his dissenting pamphlet Areopagitica (1664).

By means of the unexpected conflation of politics, scientific discoveries, and religion, England's economic and political structures were thoroughly reconfigured. While prior to that period civil society was understood as a great body whose head was the king, ${ }^{3}$ now, there were efforts to conceive English society "as a collection of ultimately independent, rational individuals" (Jordan 11). Of course, most of this applies to the idealistic young Milton, who believed that each man had a right to be guided by his reason, debunking the power of "old repute / Consent or costume" ( $P L$ 1. 639-40) $)^{4}$ which accompanied many of the rationales and justifications for absolutist-style monarchy. After all, the role of the individual as a site of critique of the totality was always haunted by the possibility of relapsing into alienation and the Satanic "myself am Hell" ( $P L$ 4. 75). However, if the youthful "liberal humanism" proved to be too idealistic for the mature Milton, his political views later in his life - he holds in The Ready and Easy Way that England should be governed, in Peter Herman's words, by "an intellectual and moral elite" (90) - scarcely are a democratic alternative.

At any rate, throughout Milton's writings we can see an attempt to come to terms with the new possibilities opened up by the so-called inner light, that interiority which "[is] a principle of constancy through time... the self's independent consciousness of its own truth" (Jordan 2). As we shall see, in Milton the integrity and trustworthiness of this consciousness as a mediator between God and men includes a concern regarding virginity and the transmission of 
original sin. Indeed, it is extremely remarkable, if not heretical, that Milton as one of the central figures of English Puritanism should be (it seems, at first) so unconstrained by the notion of his own status as fallen being, so that when he came to write his major epic he composed, in Harold Bloom's ironic phrase, as if he were "the incarnation of truth" (91). Although our exposure to German idealism and even the romantic genius-poet have made the concept of artist sharing in God's subjectivity in his creation (as He is the great subject or creator) as a somewhat faded metaphor, Milton wrote before that German tradition, in a time when this idea still retained its strangeness as a notion originated in the writings of heretics and occultists. Thus, we should not only look for the historicaleconomic reasons behind the rise of individuality, but explore the extent to which it is intertwined with proscribed, unorthodox religious ideas. After all, we must remember that Milton wrote when the word "individual" still retained its rather prelapsarian meaning of something which cannot be divided, when to say that man was as a God was more a potentiality for freedom, for "more life" in Bloom's and Nietzsche's terms, than a rationale for exploitation. ${ }^{5}$

\section{The Birth of the Poet: Confession in the Nativity Ode}

\section{The Infant silences the Oracles}

The first great achievement of Milton's career can arguably be seen in "On the Morning of Christ's Nativity," written in 1629 when the poet reached his maturity (21 years-old). ${ }^{6} \mathrm{~A}$ few years before, he had already voiced his ambition of becoming an epic poet, following the classic example of Virgil, who started writing pastorals so as to "graduate," in John Leonard's reworking of Anthony Lowe's seminal argument, into epic sublimity. As is often the case with Milton, however, the poem's most immediate subject fades into the background, and the text becomes a space for a wide-ranging exploration of the topos of poetic birth. Whereas minor poets would restrict themselves to a celebration of the attributes of Christ, in Milton's poem Christ makes his explicit appearance in only a few moments. The poem instead widens the range to meditate on the effects of the Son of God's birth over nature and the imagination of man.

As David Quint points out, in the Nativity Ode, Milton is trying to insert himself in a tradition of oracular voices. He wants to "join the Angel Choir" and to be touched by God's "hallow'd fire" (1l. 27-28), a reference to the famous vision of prophetic inspiration of Isaiah. Given that human nature is inherently corrupt in Christian theology due to original sin, the poet wants to create the illusion that his birth, like that of the Christ, is a token of hope, and a break with the reproduction of sin and in sublunary space. Analogously to the contemporary invention of the chiaroscuro technique in painting, there is an interplay between light and darkness throughout the poem, and in its most essential substrate the ode stages this "myth" of the overcoming of night by the light of day. ${ }^{7}$ Christ is "that glorious Form, that Light unsufferable" (1. 8). This is important for us 
because Milton recognizes that this archetype (i.e. the oracular figure that brings light) has been associated with poets and prophets throughout history. Moreover, he fears that like others before him, he might turn out to be a false prophet. And in order to dramatize it he contrasts Christ, the "true" prophet, with a catalogue of "false" pagan deities which were linked to Sun worship (Osiris, Moloc, Thammuz), showing awareness of the fact that the twenty-fifth of December was formerly a date for the celebration of the "birth" of the sun and sun deities.

Furthermore, as demonstrated by Quint, the form of Milton's ode is deeply related to a coral song on the birth of Apollo from Euripides, that other pagan god whose light came into being in order to overcome darkness, and who is the first to be led into prison in hell after Christ's birth, "with hollow shriek the steep of Delphos leaving" (1. 178). The assignment of this particular fate to Phoebus is all the more remarkable because Milton was in the habit of writing elegiac poetry (an originally Apollonian genre) prior to the Nativity Ode. In the letters he writes to Charles Deodati in this period, he even advises his friend to continue writing elegiac poetry, even though he has started to question its value (Quint 200-201).

One of Milton's greatest fears in "On the Morning of Christ's Nativity" is that his future career as a prophet-poet might prove to be a fantasy if he continues to be inspired by Apollo and classical figures. His intention is to become a Christian poet, yet as is evident in the poem titled "The Passion," Milton still had to come to terms with some aspects of Christianism he deemed repulsive, such as the primitive logic of sacrifice involved in Christ's death. Further, as Quint remarks, the Ode stages a premature wish for apocalyptic fulfilment, in which he sees nature restored to a prelapsarian state, in an attempt to elude the very need for redemption via sacrifice that Milton opposed. Yet, as the famous verse "But wisest fate says no, / this must not yet be so" (1. 149-150) dramatizes, Milton withholds his eagerness. He recognizes that he is still too young to be a poet inspired by God, and so he concludes the poem by simply offering his humble talent to God, standing passively "in order serviceable" before the manger. And in this recognition that his ambition to be a prophet inspired by God might be too great an expectation, he actually succeeds in poetic achievement: "Milton's first great poem succeeds in staging the failure of its fondest dreams" (195).

Moreover, one of the reasons why Milton turns away from Apollo is because elegiac poetry is "filled with a creative force that is both sexual and part of a natural cycle of regeneration ... and this force is essentially pagan" (202) and "Milton is intent on writing a non-carnal or virginal verse in this inaugural poem of his career" (200). For these reasons, the poem opens with an image of "corrupt" nature covering her sins under snow and Peace "with Turtle wing the amorous clouds dividing" (1. 50), an image that suggests Zeus and Hera making love, the voluptuousness of nature and generation that must be rejected. In order to be an inspired poet, he must endorse a type of virtuous chastity, and here in the beginning of his career it takes the form of abstention from sex. He must purify his poem from pagan culture and its celebration of bodily pleasure. 


\section{The Confessional Character of the Poem}

At first, to read the Nativity Ode autobiographically poses a problem since, although certainly occasional, as the title indicates, there is no clear link in its history of composition and a specific event in Milton's life, in the same way that we can, for example, in the cases of Lycidas (Edward King's death) and Paradise Lost 3; 1-55 (his blindness). Besides, differently from these other poems, here Milton's tone is much more distanced and apparently impersonal. The speaker figures only in the use of a, possibly royal, first-person plural, in such a way that it can actually be seen as mouthpiece for the collectively redeemed humanity.

Nonetheless, Arthur Barker has conjectured that the Ode stems from a particular religious experience which Milton must have shared with his contemporaries. Similarly to other seventeenth-century poets, whose work attest the transfiguring effects of religious conversion, Milton's Ode, in his reading, reflects precisely a kind of "rebirth" that any Puritan (or even Christian) would undergo after such a illumination: "is it possible to be more precise and to point to some particular occasion when Milton experienced an illumination corresponding to the typical exaltation of the Puritan?" (168). He interprets the break that the 1629 Ode establishes in relation to the former poems as a sign that the type of inspiration that Milton received to write it assured the poet of the divine nature of his calling: "he thenceforth thought of himself not simply, like Bunyan, as a saint but as a poet sacred to the gods and their priest" (169-170). Although the authenticity of such an experience can only remain a surmise, Milton certainly wants the reader to interpret his Ode as a form of confession of faith, as his "(re)birth." Yet to accept that the ode signals a change in Milton's poetic career (as we saw, he stopped writing elegiac poetry as he wanted to discipline himself to become a divinely inspired poet) does not entail that this new phase in his career was completely free from anxiety (that is, that he did not waver in his confidence in regard to the nature of his inspiration, as Barker's view suggests).

Thus, even though we cannot be sure whether we can correlate the poem with a true illumination or not, it is clear that, insofar as the poet acknowledges the importance of subsuming his interest in classical literature under his vocation as prophet-poet, the ode indeed stages a type of conversion/ confession. "On the Morning of Christ's Nativity" dramatizes the moment in which the poet chooses Christianity over "pagan error" at the same time that he acknowledges before the public his own susceptibility to the allure of classical literature, recognizing that his virtue is still at an immature stage. All these characteristics bring Milton's Ode closer to being a confession, given that "confessional autobiography may be the record of a transformation of errors by values; or it may be a search for values or even an attempt to justify the writer by an appeal to the lack of them" (Spender 121).

Milton's plea resembles most immediately the arrangement in Augustine's Confessions, although we can say that it follows a logic that goes back at least 
to the Old Testament, as, according to Northrop Frye, the Bible is structured around the idea that the Messiah must go through some type of "humiliation," to show his dependence on God for redemption. Despite Christian's more ready association of this pattern with Christ, it actually also plays a large role in the representation of King David and the prophets. As Frye says: "David is speaking of the necessity of his own humiliation, even in his own eyes, as a part of his royal responsibility... that certainly would account for the number of psalms that are associated with David and yet are confession psalms which express the need for forgiveness or the need for deliverance" (102). As we have seen, part of Milton's success in the Nativity Ode stems precisely from his recognition of the failure of his illusions, which is, in a sense, a type of self-abasement. Besides, this practice of kingly humiliation can be traced back to ancient Near East rituals, which, like the festivals of the solar pagan deities aforementioned, took place at the close of the year: "in Babylon at the time of the New Year festival a king... would go through a ceremony of ritual humiliation" (101).

Milton, however, had contact with confessional autobiography genre more intensely in reading Augustine. As John Savoie says, Milton probably "knew all the works of Augustine that were available to him in the seventeenth century" and the influence of the latter "spans Milton's writings" (141). As the first writer to explore the predicament of the Christian fond of classical culture and what can be saved of it, Augustine offers a model for the Protestant poet: "both Augustine and Milton thoroughly knew and loved classic Latin literature, though with reservations, and so dedicated themselves still more passionately to Scripture and God's truth" (139). Savoie further argues that whereas the moment of Augustinian confession is that of a thoroughly rejection of pagan culture, akin to Plato's renunciation of the value of poetry in The Republic, Milton offers a different solution to the dilemma. He tries to redeem pagan culture by making it subservient and useful to the Christian revelation, and by this synthesis, "Milton's greatest gift of recompense [to Augustine] is the pagan literature that Augustine had read and loved so passionately as a youth" (150).

Similarly, as we saw, Milton distances himself from Apollo and the pleasures afforded by nature, "it was no season then for her / To wanton with the Sun, her lusty Paramour" (1l. 35-6). Milton's commitment to chastity as a means of purification and assurance of the authority of his prophetic voice is also full of Augustinian echoes. In fact, here in his first mature poem we see Milton tackling the inter-relations of chastity, virginity and sex that would pervade his later work and which would become one of his most famous features. As Savoie points out, although Augustine and Milton would come to assume diametrically opposed stances, in his youth Milton still is influenced by a rather Catholic aversion to sexual energy. He shares in the later Augustine's "logical defence of continence and mystical celebration of passionate chastity" (141). The "still sexually inexperienced Milton" celebrated "unmarried virginity," a notion that later in his life would metamorphose into an evaluation of chastity within marriage, haunting his reflection on virtue in general (Savoie 142). 
In short, the Nativity Ode prefigures motifs that are to pervade the poet's work. From the outset we see that his career is presented as that of a prophetic, oracular figure, who, as a Christian, needs to reject a classical fixation on the body, which leads to a tension between two cultural heritages, best staged in confessional form. The poet's consciousness, as that of Augustine before him, dramatizes the solidification of his identity in an attempt to repress something he deeply loves and whose renunciation, although coming at a great cost, renders the conversion all the more exemplary. As Quint has shown us, the poet only succeeds by realising his immature condition, his fragile virtue.

\section{The Faithful Herdman's Art: The Anxieties of "Lycidas"}

We move on to a poem which has a crucial role in Milton's development, another crossroads in his career, so much so that he would quit writing poetry in English for a considerable time. Before discussing to which extent the poem is a culmination of previous motifs, and specifically for our purposes, of how the poet represents himself, and how he employs the pastoral genre for confessional ends, a general consideration of the poem is useful.

"Lycidas" is perhaps the most important elegy in the English language. Previous to it, as expected from the career that Milton had foreshadowed or rather pre-ordained for himself, the poet had explored the possibilities of pursuing virtue within a pastoral setting. In this Arcadian world, the pursuer of virtue is assisted by the genii loci or the "attendant spirits" who inhabit nature and are, in C. F. Stone's words, "traditional pastoral forms of divine manifestation" (869). However, in "Lycidas" Milton arrives at the critical moment (in the original sense of "crisis") of his career as an apprentice shepherd-poet, as he starts to question the validity of pastoral imagery and the trustworthiness of the inspiration it affords. "Lycidas' is aligned with 'Arcades' and Comus, but its subject calls for a repudiation of their pastoral visions" (Stone 869). If in the Nativity Ode Milton rejects pagan oracular models, in Lycidas he confronts the need to also abandon the pastoral mode.

The pastoral as a mode or even genre can be traced back to Theocritus in Ancient Greece (Arcadia, for instance, refers to a region in the Peloponnese). At the core of its conventions is the depiction of the lives of herdsmen in the countryside, even though critics are divided as to whether the genre is specifically about the landscape, and the yearning for a lost Golden Age, or the psychological state of the shepherds. Paul Alders, for one, says that "we will have a far truer idea of pastoral if we take its representative anecdote to be herdsmen and their lives, rather than landscape and idealized nature" (22). In Milton's specific case, the reinterpretation of the pastoral that Virgil makes in the Eclogues is of special importance. The Roman poet is the first to introduce an element of tension in the peaceful, atemporal landscape of the fellow shepherds (who are metaphorical poets). For instance, in the first eclogue "the idyllic landscape represents a fantasy that is dissipated by the recognition of political and social realities" (24). This 
introduction of the political world into the reality of the pastoral, as we are going to see, is essential to "Lycidas."

The occasion for Milton's re-examination of the role of pastoral in his work from the period that spans between the Nativity Ode and "Lycidas" is the death of Edward King, one of Milton's colleagues at Cambridge who died at a shipwreck, and who, more importantly, was also an aspiring poet. In the elegy, Milton, as part of a rhetorical act, demands of the nymphs, the wood spirits and the genii of the shores why they let King (Lycidas) be drowned, only to realize the limitation of these pastoral formulas. "Lycidas's death showed that the pastoral world is not linked to the divine realm as pictured in... Comus" (Stone 873).

The Nativity Ode leaves us with the poet announcing his birth through a dramatization that arises out of his anxieties towards his "immature" condition, and Milton opens his elegy for Edward King with the same motif of unreadiness. Though the "sad occasion dear" compels him "yet once more... to pluck berries harsh and crude" of the laurels and the myrtles, that is, forces him to reap the fruits of his poetic vocation (laurel is a symbol of poetic fame, as in "poet laureate"), his fingers nonetheless are "rude" and untrained. And in "Lycidas" this unreadiness proves to be threatening, as the poet confronts the possibility of having an ending similar to that of Edward King, a poet who died "in his prime," before he could achieve recognition. Moreover, for Milton, the dead body of his comrade becomes a warning of the fate that might befall him if he continues to prolong his dependence on classical inspiration.

In terms of self-figuration, the elegy becomes a potent vehicle for the writer to explore his anxiety in displaced form. As in the Nativity Ode, the poet's subjectivity does not impress the text in an explicit manner (a more Romantic practice), but only through the medium of highly conventionalized genres, forms or modes, as the confession or in our case the elegy. As Northrop Frye explains, "in pastoral elegy the poet who laments the death is often so closely associated with the dead man as to make him a kind of double or shadow of himself" (27), or in Stone's words, "[Milton's] identification with Lycidas becomes a metaphor for the confrontation with his own self" (875).

Milton grapples with the possibility of poetic failure especially in two deeply charged passages. The first has to do with the fate of the classically inspired poet which, as C. F. Stone shows, is synthetized in the dismembered dead body of Orpheus, the legendary poet (as well as musician and prophet) known for his enchanting powers over nature, who nonetheless could not be saved from his death in the hands of the fierce Bacchae. The so-called Orpheus passage (1l. 5763) is the darkest in the poem and shows Milton's terror-struck confrontation with the "gory visage" (the decapitated head) of the mythical poet. ${ }^{8}$ The fact that the muse Calliope, Orpheus's mother, could not do anything to save her son when his head "down the stream was sent / [from] the swift Hebrus to the Lesbian shore" (1. 63), becomes an emblem for the limitation of classical mediation. In Stone's words: 
Because she is a muse, her failure also represents the failure of inspiration and Milton's awareness of a similar failure in the earlier poetry. Moreover, this awareness also extends into the future because Calliope is the muse of heroic and epic poetry. Thus, the Orphean image represents Milton's sense of danger when threatened by a failure of inspiration. (870)

Every poet that does not or cannot express the word of God must necessarily drown. Therefore, in the course of the poem, the shepherds of the pastoral tradition that runs from Theocritus to Virgil and beyond are contrasted with the "pastors" of the Christian tradition. The last voice to appear in the poem, "last came and last did go" (1. 109), is that of St. Peter, the "rock" over which the church was built. Meaningfully, he is not referred by his name but as "the pilot of the Galilean lake." This verse of euphonic alliteration reminds the reader that "Peter would have drowned too without the help of Christ" (Frye 26), as in the famous passage of the Gospels in which Christ walks on the waters.

Peter warns the readers of the fact that many priests are actually corrupt and no different from their forerunners, in a stanza which disrupts the deeply fictional atmosphere of the pastoral poem and gives place to a keen political attack. Milton has been trying on different guises in search for a true inspiration and in the moment that Peter bursts into the scene, it is clear that he has achieved a more elevated mood in the "dread voice" (1. 132) of the apostle, and in some ways begins to leave the pastoral behind. Now he is going to be a shepherd only in the sense of a priest who tends his flock. As a poet of prophetic aspirations, Milton observed with pleasure that with the years his anticipation of the downfall of the clergy proved to be true. Some years later, when he republished "Lycidas" he added an introductory note that remarks that the poem "by occasion foretells the ruin of our corrupt clergy then in its height."

Another piece of evidence that "Lycidas" stages Milton's anxieties concerning himself as a poet appears in a cancelled passage. As shown in Stone's analysis of the manuscript, the "great roll-call of flowers" towards the end of the poem was a later interpolation. In an exuberant passage, the poetic voice describes the flower that hypothetically would adorn Lycidas's coffin. However, Milton represses a very meaningful flower, the Narcissus. The verse "next adde Narcissus $y^{e}$ still weeps in vain" was not included in the final version. Conjecturing possible causes, Stone says:

Like Narcissus' image before he knew it was his, the figure of Lycidas mediates Milton's self-love by disguising it as love for another... The poem acts like the pool when Narcissus believed his image to be another, reflecting another whom Milton unwittingly loves as himself. (879-880)

The appearance of the narcissus implies a confrontation with the poet's own mortality (and "Lycidas" has often been read as response to Milton's fear of death). Although throughout the poem he speaks of Lycidas as if of another, as the flower passage draws near he seems to come closer to the awareness that he 
is mourning his own subjection to death. This would disrupt the imagery of the poem which finishes on a happier note, as the dead is supposed to resurrect with the sun which always sinks in the horizon to rise again. In a complicated twist, unawareness that the poet loves Lycidas as himself means that he can also identify with Lycidas's future resurrection, making the rhetoric of the poem successful. However, the fact that he realizes his narcissistic predicament exactly when he envisions Lycidas's coffin foreshadows his death, as Narcissus similarly declines into death after he becomes conscious that it is his image in the pool. As Stone points out, all this is overwhelming and Milton must repress it.

The motif of chastity also takes a new turn. Before Peter appears, the poet traces the vacillation in his resolution, the doubts that arise out of the fellow shepherd's untimely death. Faced with the possibility that in spite of his strenuous self-restraint (the precondition for virtue) the poet might still die unrecognized, he asks what avails to "tend the homely slighted Shepherd's trade:"

Were it not better done as others use, To sport with Amaryllis in the shade, Or with the tangles of Neaera's hair? (11. 67-69)

As we saw, in the Nativity Ode the poet contemplates with pity the broken tresses of the nymphs as they are led to hell. Here in "Lycidas" we find him questioning the use of giving up the sexual pleasure associated with the nymphs, if he continues to be denied divine inspiration. In this dramatic moment Apollo bursts into the scene and affirms that "Fame is no plant that grows on mortal soil" (1. 78). Yet at times it seems that it is Milton's, so to say, "pagan" attachment to earthly fulfilment and the body that proves to be the driving force of the poem and the cause of its ambivalences. Towards its closing moment, in the flower passage we have been talking about (11. 133-164), Milton shows that he can only imagine a heavenly recompense for Lycidas's suffering in terms of a sexual climax, as the passage abounds in erotic innuendo, making reference to "wanton winds," "fresh laps" and "the green turf suck[ing] the honied showers." The bastion of virginity and self-denial increasingly becomes the radical of Paradise Lost, who claims that what distinguishes the fallen condition from the unfallen is sexual plenitude.

\section{The Inner Light: Milton's Defence}

The concluding analysis in this article is an examination of Milton's most plainly autobiographical moment in Paradise Lost, the invocation to light in book III (11. 1-55). Whereas the whole poem is composed under the rhetoric that the poet has a direct access to the Holy Spirit, in the beginning of this consequential book Milton approaches his muse cautiously. By means of a strategy similar to that of the Nativity Ode, he tries to make the recognition of a possible weakness his greatest strength-akin to the theological argument, so central to Paradise Lost, of the felix culpa. As David Loewenstein says "'my 
strength is made perfect in weakness' (2 Corinthians 12:9-10) becomes Milton's motto in the 1650s" (20).

As Paradise Lost purports to be a theodicy, as per the the proem, "[to] assert Eternal Providence / and justify the ways of God to man" (PL 1; 25-26), in the invocation of book III the poet feels the need to engage in a defence of the divine nature of his inspiration and his right to write the poem. In order to understand the need for him to defend himself, we must consider how the loss of his eyesight becomes one of the most meaningful issues that he explores later in his life.

Milton started to go blind around 1644 and by February 1652 he had completely lost his eyesight. In the period of political backlash of the Restoration, many of his royalist enemies interpreted this loss as divine punishment for his pamphlets that exculpated the regicide. Milton, however, tried to see it as divine sign. Loewenstein, for instance, says that in his Second Defence, "even as he writes as a public defender of the state, he includes a great deal of autobiographical material in defence of himself and his character" (20). The same can be said of his epic poem: he justifies God as well as his status as a divinely inspired poet. Moreover, as he argues in Sonnet 22, his eyesight was lost due to his strenuous efforts in writing political treatises and pamphlets during the revolution: "What supports me, dost thou ask? / The conscience, friend, to have lost them overplied /In liberty's defence, my noble task" (1l. 9-11).

Thus, Milton cannot escape addressing this question in his epic. For example, even though this might often be overlooked, the first two books of Paradise Lost are set in utter darkness. ${ }^{9}$ The poet is not describing the landscape of Hell realistically as if he were a nineteenth-century novelist; he is rather trying to metaphorically intimate the contours of a place that is not illuminated by any light (even hell's flames throw no light, but "darkness visible"). The escape from Hell and the speaker's contemplation of divine light in the beginning of book III thus become a momentous circumstance, pointedly because the actual poet can no longer physically see the light in real life. Rather, the "offspring of Heav'n firstborn" manifests itself as an intense inner light. He laments:

but thou [the light]

Revisit'st not these eyes, that roll in vain

To find thy piercing ray, and find no dawn;

So thick a drop serene hath quencht thir Orbs,

Or dim suffusion veil'd. $(3 ; 22-26)$

The eyes which roll (like a planet or a satellite) but find no dawn are drearily reminiscent of "Lycidas," which finishes with the sun setting to rise "tomorrow." In the elegy, the return of the sun is a token of resurrection, and here in Paradise Lost in the recognition that he might find no "dawn," Milton faces again his own mortality. Also, as often remarked, the name of Milton's illness in Latin is "gutta serena," translated as drop serene. That he mentions it so explicitly affords us a moment in which a detail of his life makes its way so visibly in the poem. 
In spite of the despondency that the loss of eyesight might cause, it is in this moment of weakness that Milton finds his strength. He is reminded that Homer, the original epic poet whom Virgil and so many others have emulated, also was blind, and so was the mythological prophet Tiresias: "Nor sometimes forget/ Those other two equall'd with me in Fate / So were I equall'd with them in renown" (ll. 32-34). In this verse, so reminiscent of Dante's Inferno IV.95-99, he appeals to the idea, classical in its origin, that blindness is actually a higher form of knowledge (as one can find on Oedipus Tyrannus). The blind prophet has visions of things past and future exactly because he is not bound to acknowledging the transitory world of appearances. In light of this, Milton's reflection on his own blindness in book III can be seen as the apotheosis of the motif of oracular inspiration which begins with his rejection of false pagan solar deities in the Nativity Ode. If, for one side, he is "cut off from the cheerful ways of men," on the other hand, the book of nature has become what every great poet has always wanted: "a Universal blanc" (1. 48) in which he can freely create, "it underscores his sense of creative potential" (Loewenstein 22). Milton finishes the invocation with an assertion of his superiority as a chosen prophet: God chose to make him blind so that he can see what is "invisible" to others: "Shine inward ... there plant eyes... that I may see and tell / Of things invisible to mortal sight" (1l. 52-55).

\section{Final Remarks}

"Sincerity is a criterion only for third-rate Romantics" (30), sentences Northrop Frye almost as an answer to Johnson's notably negative review of "Lycidas," "where there is leisure for fiction, there is little for grief." It is interesting that a poem such as "Lycidas" lends itself to an extremely autobiographical reading at the same that it is deeply conventional, so that one even questions Milton's grief over the "real" Edward King. This shows that in the seventeenth century the self could best appear as mediated by other generic conventions, as even in letters, an assumedly intimate form of communication, one might find very stylized and formulaic language. Does this imply that the self then was deeply constituted in a dialectical relation with ornament? When does the valuation of an unmediated, pure, faithful representation of the self arise?

As mentioned, the notion of autobiographical writing can be applied to Milton mutatis mutandis, particularly as drawn from an Augustinian paradigm. His selffigurations appear mostly through his handling of conventional modes and genres, and we have attempted to trace those which are considered as the forerunners of the modern autobiography, such as the confession or the apology/defence.

Especially when it comes to poetry, it is easy to read the text as "reflection" of the author's concerns. Yet, what distinguishes our attempt here is that we analysed a poet who, beyond his revolutionary politics, was about to change the experience of poets and the reach of their power through his trust in an inner light, an interiority that extends to encompass the cosmos. Of course, we must remember yet once more that for Milton this interiority can only be so powerful 
through its dependence on God, which perhaps distinguishes it from the Satanic degeneration in the solipsistic "selfhood" that Blake criticized.

Notes

1. See Jordan, M. Milton and Modernity (New York: Palgrave, 2001), 2. "Paradise Lost [fixes] 'the ruling assumptions, values and meanings of the modern epoch', above all its 'commitment to man, whose essence is freedom"'(his italics).

2. See Jameson, F. "A Political Reading of Paradise Lost" in Literature, Politics and Theory (London: Routledge, 2007), 38-39: "religion [is] the privileged mode in which a pre-capitalist collectivity comes to consciousness of itself and affirms its unity as a group ... and become aware of their political differences and fight them out."

3. As crystallized in Hamlet 3.1.23-24, "that body / whereof he is the head."

4. All the references to the poems by Milton discussed here are taken from the standard Merritt Y. Hughes edition. Hughes, M. Y. John Milton: Complete Poems and Major Prose. Indianapolis: Hackett, 2003 [1957].

5. See Eagleton, T. Ideology: An Introduction (New York: Routledge, 1994), 60: "When the middle class was still an emergent political force, its revolutionary rallying cry of liberty was certainly, among other, finer things, a rationalization of the freedom to exploit."

6. Helen Vendler, alternatively, dates Milton's maturity as a poet to the later composition of "L'Allegro" (1631) by identifying irresolvable contradictions in the "Nativity Ode". See her Coming of Age as a Poet for the argument in favour of "LAAllegro" (1-40).

7. As if in preparation for the Nativity Ode, Milton had argued for the side of "Day" in an exercise in oratory when he was still a student at Christ's College, Cambridge. In this prolusion, written in Latin and translated as "Prolusion 1: Delivered in the College, Whether Day or Night is the More Excellent," we also find the alternation of night into day reversed (Hughes 595).

8. See Luiz Fernando's F. Sás recently published monograph The Orpheus Myth in Milton's "LAllegro," "Il Penseroso," and "Lycidas:" A Peircean Reading for a comparison of the uses Milton makes of this myth across his early works.

9. See "The Return of Eden" in Northrop Frye on Milton and Blake (Toronto: Toronto University Press, 2005), 46: "At the opening of the poem we find ourselves plunged into the darkness of hell and eventually, after our pupils have expanded, look around and see one or two lights glaring."

\section{References}

Alpers, Paul. What is Pastoral? The University of Chicago Press, 1997.

Barker, Arthur. “The Pattern of Milton's Nativity Ode.” University of Toronto Quarterly, vol. 10, no. 2, 1941, 167-181.

Bloom, Harold. “Milton.” Ruin the Sacred Truths. Harvard University Press, 1991. 89-114.

Frye, Northrop. "Literature as Context: Milton's Lycidas." Collected Works of Northrop Frye: Northrop Frye on Milton and Blake. Edited by Angela Esterhammer. University of Toronto Press, 2005. 24-34.

Frye, Northrop; MacPherson, Jay. “The Metaphor of Kingship.” Biblical and Classical Myths: The Mythological Framework of Western Culture. University of Toronto Press, 2004. 99-109. 
Herman, Peter C. Destabilizing Milton: Paradise Lost and the Poetics of Incertitude. Palgrave, 2005.

Hugues, Merrit Y (ed.). John Milton: Complete Poems and Major Prose. Hackett, 1957. Print.

Neuse, Richard. "Milton and Spencer: The Virgilian Triad Revisited." ELH, vol. 45, n. 4, 1978, 606-639.

Jameson, Fredric. "Religion and Ideology: A Political Reading of Paradise Lost." Edited by Barker, F. et all. Literature, Politics and Theory. Routledge, 2007.

Jordan, Matthew. Milton and Modernity: Politics, Masculinity and Paradise Lost. Palgrave, 2001.

LEJEUNE, Philippe. Le Pacte Autobiographique. Paris: Seiul, 1975.

Leonard, John; Milton, John. "Introduction.” Paradise Lost. Penguin Books, 2003.

Loewenstein, David. Milton: Paradise Lost. Cambridge University Press, 2004.

Low, Anthony. The Georgic Revolution. Princeton University Press, 1985.

Olney, James. "A Theory of Autobiography: My Metaphysics... My Physics." Metaphors of the Self: The Meaning of Autobiography. Princeton University Press, 1981. 3-50.

Quint, David. "Expectation and Prematurity in Milton's 'Nativity Ode." Modern Philology, vol. 97, n. 2, 1999, 195-219.

Rogers, John. The Matter of Revolution. Cornell University Press, 1996.

Sá, L. F. F. The Orpheus Myth in Milton's "LAllegro," "Il Penseroso," and "Lycidas:" A Peircean Reading. Cambridge Scholars Publishing, 2018.

Savoie, John. "Justifying the Ways of God and Man: Theodicy in Augustine and Milton." Augustine and Literature. Edited by R. P. Kennedy, K. Paffenroth, J. Doody. Rowman \& Littlefield Publishers, 2006. 139-156.

Spender, Stephen. "Confessions and Autobiography." Autobiography: Essays Theoretical and Critical. Edited by James Olney. Princeton University Press, 1980. 115-122.

Stone III, C.F. "Milton's Self-concerns and Manuscript Revisions in Lycidas." MLN: Comparative Literature, vol. 83, n. 6, 1968, 867-881.

Treadwell, James. Autobiographical Writing and British Literature 1783-1834. Oxford University Press, 2006.

Vendler, Helen. Coming of Age as a Poet. Harvard University Press, 2003.

Recebido em: 15/06/2018

Aceito em: 19/08/2018 